\title{
SISTEM PAKAR DIAGNOSA AUTISME PADA ANAK BERBASIS ANDROID
}

\author{
Nurhakim, Frisma Handayanna, Rinawati \\ Sekolah Tinggi Manajemen Informatika dan Komputer Nusa Mandiri \\ (STMIK Nusa Mandiri) \\ Jl. Kramat Raya No. 18 Jakarta Pusat \\ http://www.nusamandiri.ac.id \\ nurhakim084@gmail.com,frisma.fha@nusamandiri.ac.id,rinawati riw@nusamandiri.ac.id
}

\begin{abstract}
Autism is a developmental disorder in children that causes child is difficult do communicte and interact socially. An expert system identification and treatment of autistic children based on android has not been widely applied, ussually only done manually based on the identification of a Psychologist assessment. Identification expert system is expected to assist in the identification of children with autism are much faster and accurate approach using data from Psychologists and special needs teachers. Knowledge in the expert system is represented in the form of rules and methods of reasoning and used method of trace forward chaining. Output on a system such as whether Three si The possibility of autism in child based on facts bor symptoms given to the system. The test results shaw that the system of identification Ana treatment of autistic children to help in the identification of children with autism and provide general description of the autistic child. In addition, there is also general information on children with autism and theirs methods of theraphy for children with autism in accordance with the conditions of the child.
\end{abstract}

Keywords: Expert System, Autism, Android, Forward Chaining.

\begin{abstract}
Abstrak
Autisme merupakan gangguan perkembangan pada anak yang menyebabkan seorang anak sulit untuk berkomunikasi dan berinteraksi sosial. Sistem pakar identifikasi dan penanganan anak autis berbasis android belum banyak diterapkan, biasanya hanya dilakukan secara manual berdasarkan identifikasi dari penilaian Psikolog. Sistem pakar identifikasi ini diharapkan dapat membantu dalam proses identifikasi anak autis secara lebih cepat dan mendekati akurat menggunakan data dari psikolog dan guru berkebutuhan khusus. Pengetahuan pada sistem pakar ini direpresentasikan dalam bentuk aturan dan metode penalaran yang digunakan adalah metode runut maju (forward chainning). Keluaran pada sistem berupa ada tidaknya kemungkinan autisme pada seorang anak berdasarkan fakta atau gejala yang diberikan kepada sistem. Hasil pengujian menunjukkan bahwa sistem identifikasi dan penanganan anak autis membantu dalam proses identifikasi anak autis dan memberikan gambaran secara umum tentang anak autis. Selain itu, tersedia juga informasi umum mengenai anak autis beserta metode terapi bagi anak autis sesuai dengan kondisi anak tersebut.
\end{abstract}

Kata kunci: Sistem Pakar, Autisme, Android, Forward Chaining. 


\section{PENDAHULUAN}

Salah satu gangguan psikologis dalam tumbuh kembang yang sering terjadi belakangan ini adalah autisme yaitu ketidaknormalan perkembangan mental yang menyebabkan anak sulit untuk berinteraksi sosial. Diagnosa autisme biasanya dilakukan oleh seorang pakar khususnya psikolog atau dokter di bidang tumbuh kembang anak. Namun, saat ini banyak anak dengan gangguan autisme yang telat dideteksi dan lambat dalam penanganannya dikarenakan mahalnya biaya konsultasi dengan dokter atau psikolog serta masih banyak orangtua yang masih awam mengenai anak autis. Sebenarnya orang tua juga dapat melakukan diagnosa awal kemungkinan autisme pada anak dengan melakukan pengamatan perilaku anak dalam kesehariannya terutama dari cara berkomunikasi, berinteraksi sosial dengan anak sebayanya, dan kemampuan berimajinasi pada anak.

Psikologis pada anak sangat menunjang tumbuh kembang pada anak. Dengan demikian dibutuhkan sebuah sistem pakar yang merupakan perangkat lunak pengambil keputusan yang mampu mencapai tingkat performa yang sebanding seorang pakar dalam bidang masalah yang khusus dan sempit. Sistem pakar mengatasi perilaku buruk masalah psikoligis pada anak dapat membantu seseorang untuk mengatasi perilaku buruk tentang psikologis pada anak berdasarkan dari pengetahuan gejala dan keluhan yang dirasakan pasien yaitu pasien adalah orang tua dari anak, sehingga dapat melakukan pencegahan dan pengobatan awal yang nantinya tidak menyebabkan anak mengalami gangguan psikologis [1].

Sistem identifikasi dan penanganan anak autis berbasis android belum banyak diterapkan, biasanya hanya manual berdasarkan identifikasi dari penilaian psikolog. Kemajuan teknologi informasi saat ini sangatlah pesat, dilihat dari bertambahnya pengguna smartphone android di Indonesia. Sehingga, diharapkan dengan sistem pakar berbasis android ini dapat membantu proses identifikasi anak autis secara lebih cepat, terutama bagi para orang tua yang masih awam tentang anak autis.

\section{METODOLOGI PENELITIAN}

\subsection{Sistem pakar (Expert System)}

"Sistem pakar atau Expert System disebut juga dengan Knowledge Based System adalah suatu aplikasi komputer yang ditujukan untuk membantu pengambilan keputusan atau pemecahan persoalan dalam bidang yang spesifik" [2].

Terdapat empat orang yang terlibat dalam lingkungan sistem pakar yaitu [3]:

a. Pakar (Expert)

Pakar adalah seorang individu yang memiliki pengetahuan khusus, pemahaman, pengalaman dan metode-metode yang digunakan untuk memecahkan persoalan dalam bidang tertentu.

b. Pembangun atau pembuat pengetahuan (Knowledge Engineer)

Pembangun pengetahuan memiliki tugas utama menerjemahkan dan merepresentasikan pengetahuan yang diperoleh dari pakar, baik berupa pengalaman pakar dalam menyelesaikan masalah maupun sumber terdokumentasikan lainnya ke dalam bentuk yang bisa diterima oleh sistem pakar.

c. Pembangun atau pembuat sistem (System Engineer) 
Pembangun sistem adalah orang yang bertugas merancang antarmuka pemakai sistem pakar, merancang pengetahuan yang sudah diterjemahkan oleh pembangun pengetahuan ke dalam bentuk yang sesuai dan dapat diterima oleh sistem pakar dan mengimplementasikannya ke dalam mesin inferensi.

d. Pengguna (user)

Komponen-komponen sistem pakar dalam kedua bagian tersebut dapat dilihat dalam Gambar II.1.

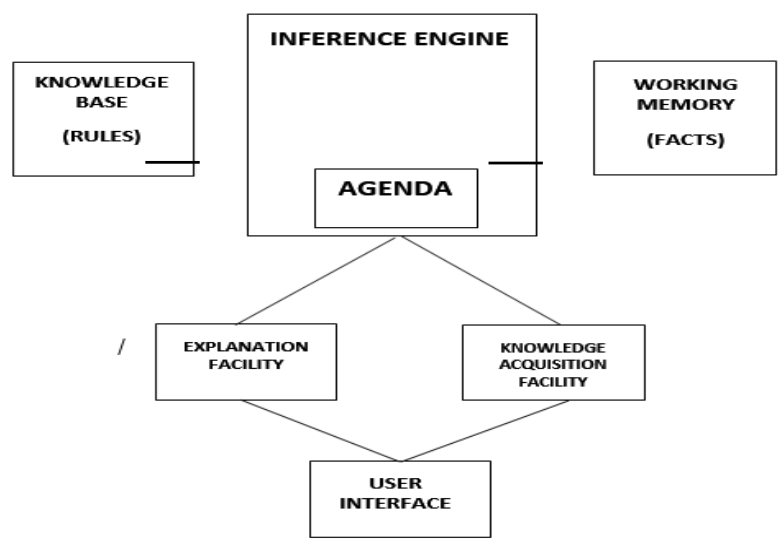

Gambar 1. Struktur Sistem Pakar

(Sumber : Rosnelly (2012))

\subsection{Autisme}

Autisme adalah gangguan perkembangan yang sangat kompleks pada anak. Seringkali gejala tampak sebelum anak mencapai usia 3 tahun. Autisme lebih tepat dikatakan sebuah sindrom, yang merupakan kumpulan gejala yang seringkali berbeda pada tiap individu dan tiap keadaan. Gejala dan perlakuan terhadap anak penderita autis berbeda. Anak autisme mengalami gangguan berkomunikasi, interaksi sosial, perilaku, emosi, serta proses sensoris [4].

\subsection{Metode Inferensi}

Metode inferensi berperan sebagai otak dari sistem pakar. Mesin inferensi berfungsi memandu proses penalaran terhadap suatu kondisi, berdasarkan basis pengetahuan yang tersedia. Di dalam metode inferensi terjadi proses untuk memanipulasi dan mengarahkan kaidah, model, dan fakta yang disimpan dalam basis pengetahuan dalam rangka mencapai solusi/kesimpulan. Dalam prosesnya, metode inferensi menggunakan strategi penalaran dan strategi pengendalian. Sistem pakar adalah aplikasi berbasis komputer yang digunakan untuk menyelesaikan masalah sebagaimana yang dipikirkan oleh pakar [5].

Ada 2 pendekatan dalam menentukan metode inferensi, yaitu sebagai berikut [5]:

1. Runut Maju (Forward Chaining)

Runut maju atau pelacakan ke depan berarti menggunakan himpunan aturan kondisi-aksi. Dalam metode ini, data digunakan untuk menentukan aturan mana yang akan dijalankan, kemudian aturan tersebut dijalankan. Mungkin proses menmbahkan data ke memori kerja. Proses diulang sampai ditemukan satu hasil. Pelacakan ke depan mencari fakta yang sesuai dengan bagian $I F$ dari 
aturan IF-THEN [5] Gambar diagram pelacakan ke depan dapat dilihat pada gambar di bawah ini:

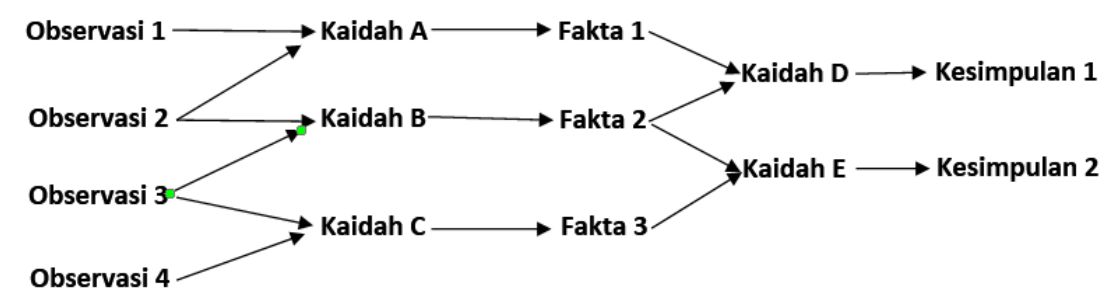

\section{Gambar 2. Gambar Diagram Pelacakan Ke Depan (Forward Chaining)}

2. Runut Balik (Backward Chaining)

(Sumber : Hayadi (2016:7))

Runut Balik atau pelacakan ke belakang merupakan metode penalaran kebalikan dari runut maju. Dalam runut balik penalaran dimulai dengan tujuan kemudian merunut balik ke jalur yang akan mengarahkan ke tujuan tersebut. Runut balik disebut juga sebagai goal-driven reasoning, merupakan cara yang efisien untuk memecahkan masalah yang dimodelkan sebagai masalah pemilihan terstruktur [5]Gambar diagram pelacakan ke belakang dapat dilihat pada gambar di bawah ini:

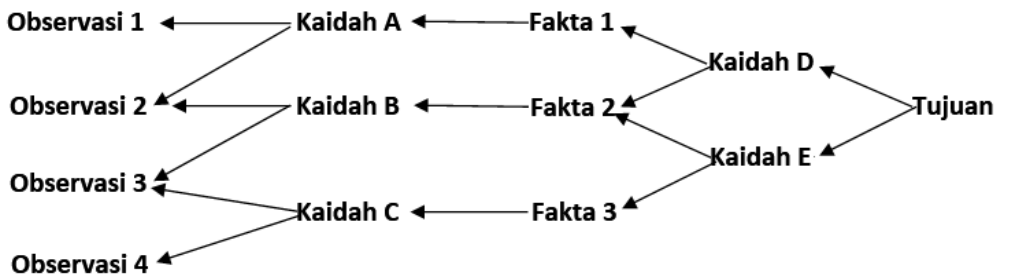

\section{Gambar 3. Gambar Diagram Pelacakan ke Belakang (Beckward Chaining)}

(Sumber : Hayadi (2016:8))

Kedua metode inferensi tersebut dipengaruhi oleh tiga macam penelusuran, yaitu:

a. Depth-first search, melakukan penelusuran kaidah secara mendalam dari simpul akar bergerak menurun ke tingkat dalam yang berurutan.

b. Breadth-first search, bergerak dari simpul akar, simpul yang ada pada setiap tingkat diuji sebelum pindah ke tingkat selanjutnya.

c. Best-first search, bekerja berdasarkan kombinasi kedua metode sebelumnya.

\subsection{Metode Penelitian}

Penelitian dilakukan dengan metode penelitian kuantitatif. Yaitu dengan melakukan

1. Observasi, menggunakan metode ini dengan menguji hasil dari permasalahan dengan mencari banyak referensi. Dengan melakukan pengamatan dan menganalisis gangguan autisme

2. Wawancara

Melakukan tanya jawab (wawancara) kepada guru dan terapis di Sekolah Citra Anindya. 


\section{HASIL DAN PEMBAHASAN}

\subsection{Pengumpulan Data Pakar}

\begin{tabular}{|l|l|l|l|}
\multicolumn{4}{|c}{ Tabel 1. Objek Pakar } \\
\hline 1 & Nama & $:$ & Farida Utami, M.Psi \\
\hline & Alamat & $:$ & Depok \\
\hline & Jabatan & $:$ & Psikolog \\
\hline & RiwayatPendidikan & $:$ & S2 Psikologi \\
\hline & Lama Bekerja & $:$ & 2008 - hingga sekarang \\
\hline 2 & Nama & $:$ & Nila Susanti, S.Psi \\
\hline & Alamat & $:$ & Ciledug \\
\hline & Jabatan & $:$ & Guru ABK (Anak Berkebutuhan Khusus) \\
\hline & RiwayatPendidikan & $:$ & S1 Psikologi \\
\hline & Lama Bekerja & $:$ & 2008 - hingga sekarang \\
\hline 3 & Nama & $:$ & Lastri Fajriah, S.Psi \\
\hline & Alamat & $:$ & Pademangan Serpong Tangerang \\
\hline & Jabatan & $:$ & Guru ABK (Anak Berkebutuhan Khusus) \\
\hline & RiwayatPendidikan & $:$ & S1 Psikologi \\
\hline & Lama Bekerja & $:$ & 2006 - hingga sekarang \\
\hline 4 & Nama & $:$ & EasyMarganing Rahayu, S.Psi \\
\hline & Alamat & $:$ & Gang Duku II No.96 Pinang Tangerang \\
\hline & Jabatan & $:$ & Guru ABK (Anak Berkebutuhan Khusus) \\
\hline & RiwayatPendidikan & $:$ & S1 Psikologi \\
\hline & Lama Bekerja & $:$ & 2006 - hingga sekarang \\
\hline
\end{tabular}

\subsection{Hasil Wawancara Pakar}

1. Autisme (untuk usia 0-1 Tahun)
a. Tidak melakukan kontak mata.
b. Tampak tenang dan jarang menangis.
c. Jarang mengoceh.
d. Asyik dengan keadaannya sendiri.

2. Autisme (untuk usia 1-2 Tahun)
a. Tidak merespon saat dipanggil namanya.
b. Sulit mempertahankan kontak mata.
c. Tidak tertarik dengan anak lain.
d. Melakukan gerakan yang tidak umum.
e. Mengalami hambatan bahasa.

3. Autisme infantil (untuk usia 2-5 Tahun)
a. Tidak mampu melakukan permainan pura-pura.
b. Tidak tertarik dengan anak lain.
c. Tidak merespon saat dipanggil namanya.
d. Tertarik pada bagian dari mainan.
e. Tidak memahami sikap tubuh orang lain.

4. Sindrom Asperger (untuk usia 2-5 Tahun)
a. Tidak hambatan dalam dalam perkembangan bahasa.
b. Pola perilaku, perhatian, dan aktivitas yang terbatas dan berulang-ulang.
c. Sulit berbaur dengan lingkungan sosial.
d. Suka memberikan pertanyaan yang monoton. 
e. Tidak sabar dalam menunggu giliran.

f. Suka lompat-lompat dan berjalan mondar-mandir.

g. Tidak ada timbal balik sosial dan emosi.

5. ADHD atau AttentionDeficitHyperactiveDisorder (untuk usia 2-5 Tahun)

a. Sulit mempertahankan atensi

b. Menghindari untuk terlibat dalam tugas yang memerlukan waktu yang lama.

c. Banyak melakukan gerakan yang diulang-ulang dan tidak bermakna.

d. Keterlambatan berbahasa.

e. Mengalami kesulitan dalam aktivitas mengisi waktu luang dengan tenang.

f. Suka membeo.

\subsection{Algoritma Sistem Pakar}

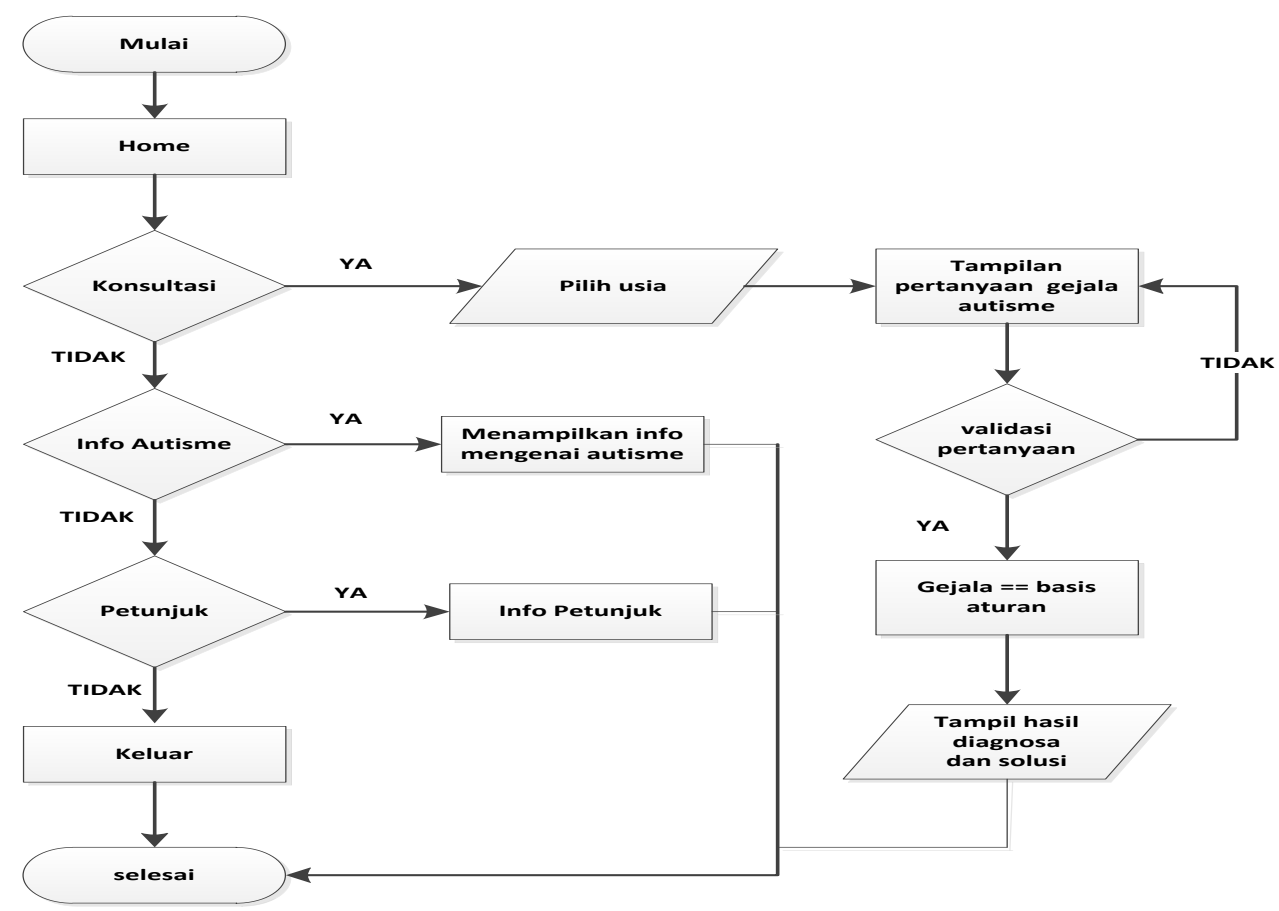

Gambar 4. Rancangan Algoritma Sistem Pakar

\subsection{Basis Pengetahuan}

\section{Tabel Pakar}

Basis pengetahuan merupakan pengetahuan penting dari suatu sistem pakar, besar kecilnya kemampuan sistem pakar biasanya ditentukan oleh kapasitas dari basis pengetahuannya, sedangkan mesin pengambil keputusan adalah aplikasi yang membantu dan memandu pengguna sistem pakar dalam memanipulasi data dan memilih pengetahuan yang sesuai untuk mendapatkan pengetahuan. 
Tabel 2. Tabel Pakar

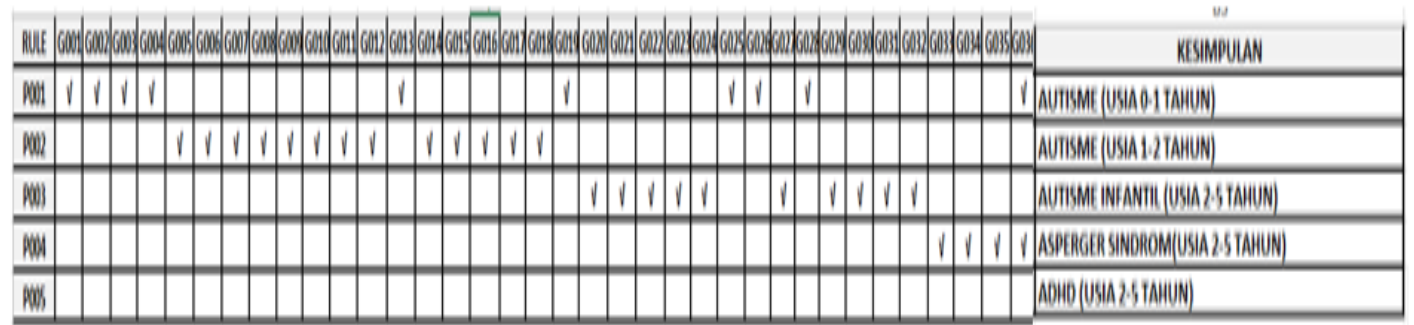

Keterangan:

Kolom pertama menerangkan rule macam-macam gangguan autisme pada pakar. Baris pertama menerangkan indikasi-indikasi gejala autisme pada pakar. Tanda square root menunujukkan gejala apa saja yang digunakan pada pakar Kolom kesimpulan menerangkan nama gangguan autisme yang dihasilkan dari indikasi gejala.

\section{Rule-rule pada Pakar}

Rule 1:

Jika tampak tenang dan jarang menangis dan jarang mengoceh dan asyik dengan keadaannya sendiri dan tidak melakukan kontak mata Maka anak terindikasi gangguan Autisme (usia 0-1 Tahun).

Rule 2:

Jika tidak merespon saat dipanggil namanya dan sulit mempertahankan kontak mata dan tidak tertarik dengan anak lain dan melakukan gerakan yang tidak umum dan mengalami hambatan berbahasa Maka anak terindikasi gangguan Autisme (usia 1-2 Tahun).

Rule 3 :

Jika tidak mampu melakukan permainan pura-pura dan tidak tertarik dengan anak lain dan tidak merespon saat dipanggil namanya dan tertarik pada bagian dari mainan dan tidak memahami sikap tubuh orang lain Maka anak terindikasi gangguan Autisme (usia 2-5 Tahun).

Rule 4 :

Jika pola perilaku, perhatian, dana ktivitas yang terbatas dan berulang-ulang dan sulit berbaur dengan lingkungan sosial dan suka memberikan pertanyaan yang monoton dan tidak sabar dalam menunggu giliran dan suka lompat-lompat dan berjalan mondar-mandir dan tidak ada timbal balik sosial dan emosi Maka anak terindikasi gangguan Asperger (usia 2-5 Tahun).

Rule 5 :

Jika sulit mempertahankan atensi dan menghindari untuk terlibat dalamtugas yang memerlukan waktu yang lama dan banyak melakukan gerakan yang diulangulang dan tidak bermakna dan suka membeo dan keterlambatan dalam berbahasa dan mengalami kesulitan dalam aktivitas mengisi waktu luang dengan tenang Maka anak terindikasi gangguan ADHD atau Attention Deficit Hyperactive Disorder (usia 2-5 Tahun). 


\section{PohonKeputusanPakar}

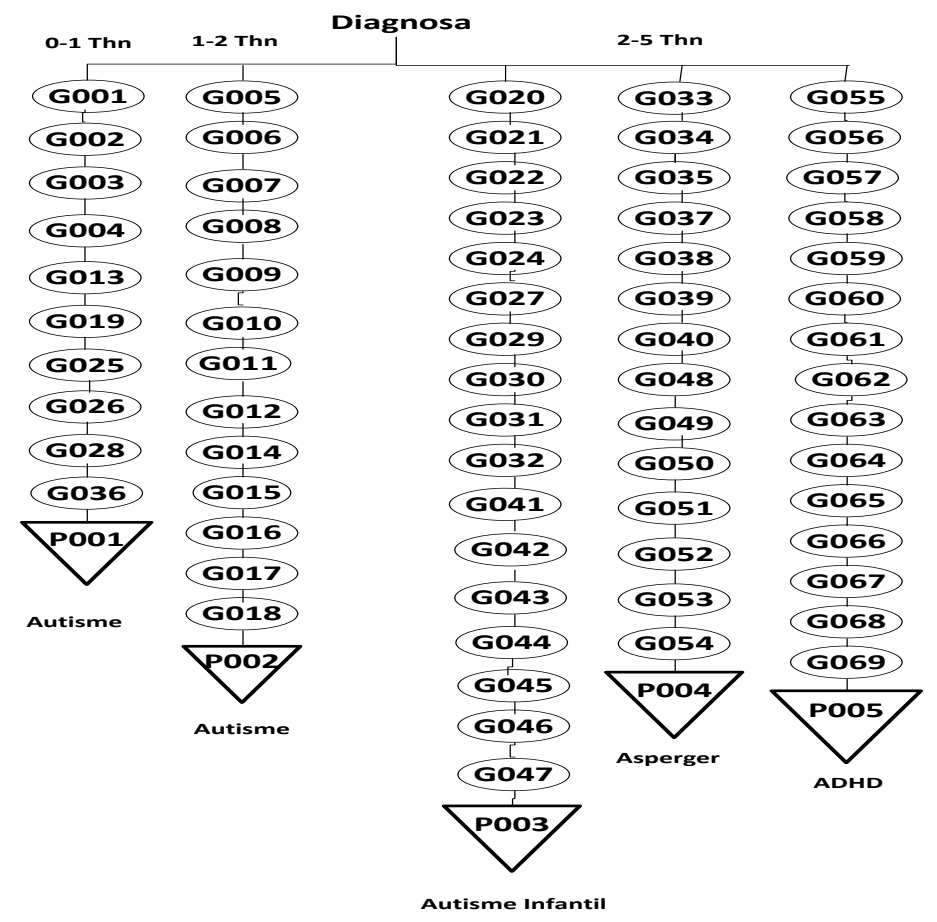

Gambar 5. Pohon Keputusan Pakar

Tabel 3. Keterangan Indikasi

\begin{tabular}{|l|l|}
\hline G001 & Bayi tampak tenang dan jarang menangis. \\
\hline G002 & Sulit bila digendong. \\
\hline G003 & Tidak mengoceh. \\
\hline G004 & Tidak senang diayun di lutut. \\
\hline G005 & Tidak tertarik dengan anak lain. \\
\hline G006 & Tidak suka memanjat benda seperti tangga. \\
\hline G007 & Tidak senang bermain petak umpet atau cilukba. \\
\hline G008 & Tidak suka bermain pura-pura misal masak-masakan. \\
\hline G009 & Tidak pernah meminta sesuatu dengan menunjuk jari. \\
\hline G010 & $\begin{array}{l}\text { Tidak pernah menggunakan jari untuk menunjuk ke sesuatu agar orang melihat ke } \\
\text { sana. }\end{array}$ \\
\hline G011 & $\begin{array}{l}\text { Tidak dapat bermain dengan mainan kecil seperti mobil-mobilan atau balok } \\
\text { mainan. }\end{array}$ \\
\hline G012 & Tidak pernah membawa dan memperlihatkan barang-barang kepada orang lain. \\
\hline G013 & Tidak mau menatap mata. \\
\hline G014 & Tidak bisa menjaga kontak mata min 10 detik. \\
\hline G015 & Tidak merespon saat dipanggil namanya. \\
\hline G016 & Tidak merespon jika kita menunjukkan sesuatu. \\
\hline G017 & Tidak peduli dengan orang lain didekatnya. \\
\hline G018 & $\begin{array}{l}\text { Menyukai secara berlebihan pada suatu bagian benda seperti roda pada mobil- } \\
\text { mobilan dan memandanginya dalam waktu lama. }\end{array}$ \\
\hline G019 & Perkembangannya agak terlambat misal dalam berjalan ataupun berkomunikasi. \\
\hline G020 & Tidak berminat terhadap mainan seperti bola, mobil-mobilan, boneka. \\
\hline G021 & Suka memperhatikan dan memainkan jari-jarinya di depanmata. \\
\hline
\end{tabular}


Jurnal Sains Komputer \& Informatika (J-SAKTI)

Volume (1) No. 2 September 2017

ISSN:2548-9771/EISSN: 2549-7200

http://tunasbangsa.ac.id/ejurnal/index.php/jsakti

\begin{tabular}{|c|c|}
\hline G022 & Tertarik pada benda yang bergerak atau berputar misal kipas angin, roda berputar. \\
\hline G023 & $\begin{array}{l}\text { Suka melompat-lompat atau mengepak-ngepakkan tangan tanpa tujuan min } 30 \\
\text { menit. }\end{array}$ \\
\hline G024 & Panik hingga menutup telinga jika mendengar suara keras maupun lirih. \\
\hline G025 & Menolak untuk dipeluk. \\
\hline G026 & Suka tiba-tiba menangis atau tertawa tanpa sebab. \\
\hline G027 & Sering kali berjalan mondar-mandir tanpa tujuan. \\
\hline G028 & Bermain dengan benda yang bukan mainan misal ujung selimut. \\
\hline G029 & Kurang imajinatif dalam permainan. \\
\hline G030 & Suka bermain dengan cahaya atau pantulan. \\
\hline G031 & Tidak berminat terhadap pembicaraan atau aktivitas di sekitarnya. \\
\hline G032 & Tidak bisa menunjukkan ekspresi wajah marah, senang, sedih. \\
\hline G033 & Tidak bisa atau jarang memulai sebuah komunikasi dengan orang. \\
\hline G034 & Tidak bisa memahami perintah yang diberikan. \\
\hline G035 & Terlihat asik jika dibiarkan sendiri. \\
\hline G036 & Tidak ada senyum sosial saat bertemu orang lain. \\
\hline G037 & Tidak bisa melakukan permainan bergiliran dengan teman. \\
\hline G038 & Suka menarik-narik tangan orang lain jika menginginkan sesuatu. \\
\hline G039 & Sangat marah jika jika terjadi perubahan dalam suatu hal. \\
\hline G040 & $\begin{array}{l}\text { Terbentuk suatu rutinitas yang kaku memakai baju tertentu atau berjalan tanpa } \\
\text { henti. }\end{array}$ \\
\hline G041 & Belum mampu berbicara atau mengucapkan kata sesuai usianya. \\
\hline G042 & Seperti mengalami gangguan pendengaran, tidak merespon saat dipaanggil. \\
\hline G043 & Tidak berminat untuk belajar bicara, tidak mau menirukan suara. \\
\hline G044 & Sukamenyakitidirisendiridenganmenggigitataumencakar. \\
\hline G045 & Tidakdapatmenyatakankeinginannyadengan kata-kata. \\
\hline G046 & Suka membeo, meniru kata atau kalimat saat ditanya orang lain. \\
\hline G047 & Suka meracau, suka mengucapkan kata aneh yang tidak ada artinya berulang-ulang. \\
\hline G048 & $\begin{array}{l}\text { Sangat spontan atau sangat cepat dalam mengucapkan sesuatu dan sering menyela } \\
\text { pembicaraan orang lain. }\end{array}$ \\
\hline G049 & Sering bernyanyi tapi tidak mengerti arti nyanyiannya. \\
\hline G050 & Tidak mempunyai rasa takut terhadap benda atau binatang berbahaya. \\
\hline G051 & $\begin{array}{l}\text { Walaupun memakai tata bahasa yang baik dalam berbicara tetapi sering mengulang } \\
\text { kata-kata yang sama dengan artikulasi yang tidakbaik dan tanpa intonasi. }\end{array}$ \\
\hline G052 & $\begin{array}{l}\text { Sering mencari perhatian dengan berbicara keras dan tidak peduli bila orang lain } \\
\text { dengan tujuan ingin mengalihkan pembicaraan ketopik lain. }\end{array}$ \\
\hline G053 & $\begin{array}{l}\text { Tidak memiliki rasa humor atau tidak merespon untuk tertawa dan tidak mengerti } \\
\text { bila orang lain bercanda atau membuat lelucon. }\end{array}$ \\
\hline G054 & $\begin{array}{l}\text { Gaya bicaranya sangat monoton, kaku dan datar serta sangat cepat, tidak seperti } \\
\text { pada umumnya. }\end{array}$ \\
\hline G055 & Gagal dalam menyimak suatu yang rinci misal instruksi. \\
\hline G056 & Sulit bertahan pada satu aktifitas. \\
\hline G057 & Cepat beralih perhatian pada stimulus atau rangsangan dari luar. \\
\hline G058 & Menghindar dari kegiatan yang memerlukan perhatian lama misal bermain puzzle. \\
\hline G059 & Saat ditanya sering menjawab sebelum pertanyaan selesai. \\
\hline G060 & Sering memotong atau menyela pembicaraan orang. \\
\hline G061 & Tidak sabar dalam menunggu giliran. \\
\hline G062 & Sembrono, melakukan tindakan berbahaya \\
\hline G063 & Permintaan harus segera dipenuhi. \\
\hline G064 & Sangat usil dan suka mengganggu anak lainnya. \\
\hline G065 & Mudah frustasi dan putus asa. \\
\hline G066 & Tidak bisa diam, selalu menggerakan kaki atau tangan dan sering menggeliat \\
\hline G067 & it melakukan kegiatan dengan tenang. \\
\hline
\end{tabular}




\begin{tabular}{|l|l|}
\hline G068 & Sering berbicara berlebihan atau tanpa henti. \\
\hline G069 & Sering bergerak seolah diatur oleh motor penggerak. \\
\hline
\end{tabular}

Keterangan gangguan penyakit :

P001 Autisme (untuk usia 0-1 Tahun).

P002 Autisme (untuk usia 1-2 Tahun).

P003 Autisme Infantil(untuk usia 2-5 Tahun).

P004 Asperger Sindrom (untuk usia 2-5 Tahun).

P005 ADHD (Attention Deficit Hyperactive Disorder) (untuk usia 2-5 Tahun

\subsection{Implementasi Dan Pengujian Sistem}

\section{Desain Entity Relationship Diagram (ERD)}

Berikut ERD yang penulis gunakan pada sistem pakar diagnosa autisme pada anak adalah sebagai berikut:

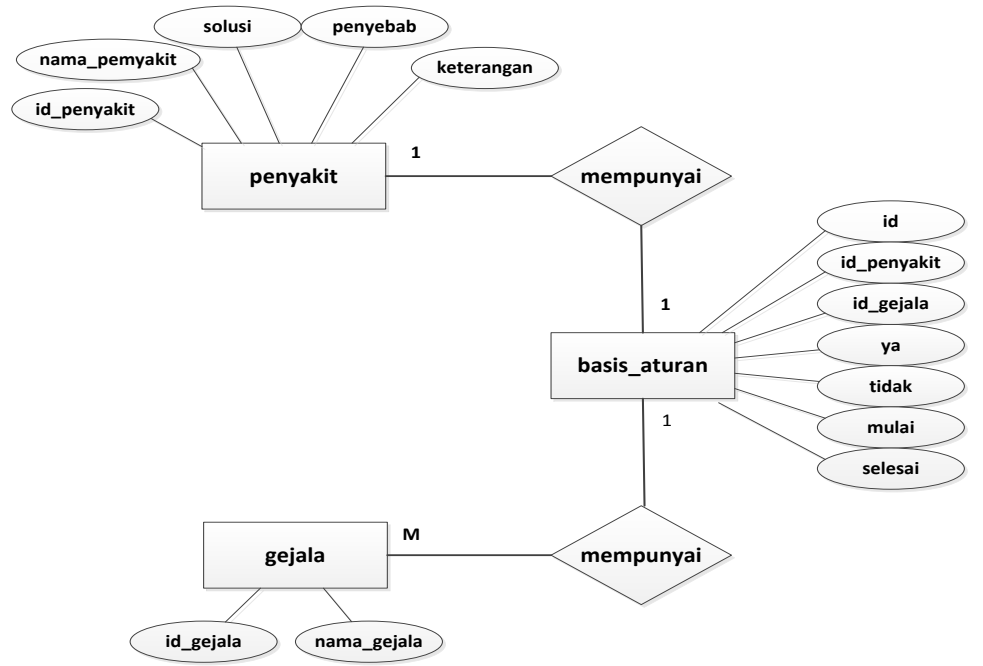

Gambar 6. Entity Relationship Diagram (ERD)

\section{User Interface}

a. Tampilan Pilihan Menu Aplikasi Sistem Pakar

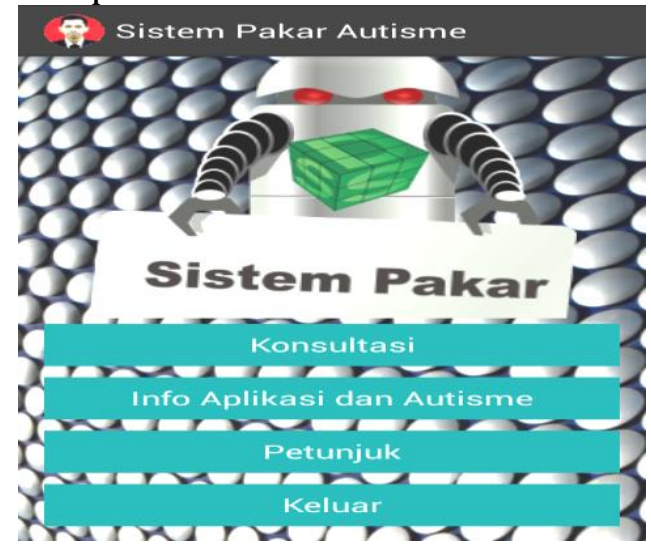

Gambar 7. Tampilan Pilihan Menu Aplikasi Sistem Pakar 
b. Tampilan Menu Informasi Seputar Autisme

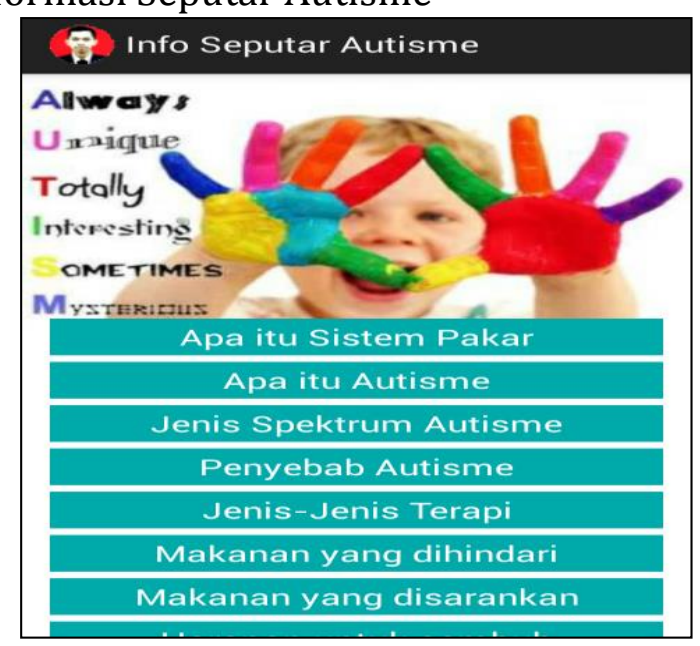

\section{Gambar 8. Tampilan Informasi Seputar Autisme}

c. Tampilan Menu Petunjuk Aplikasi.

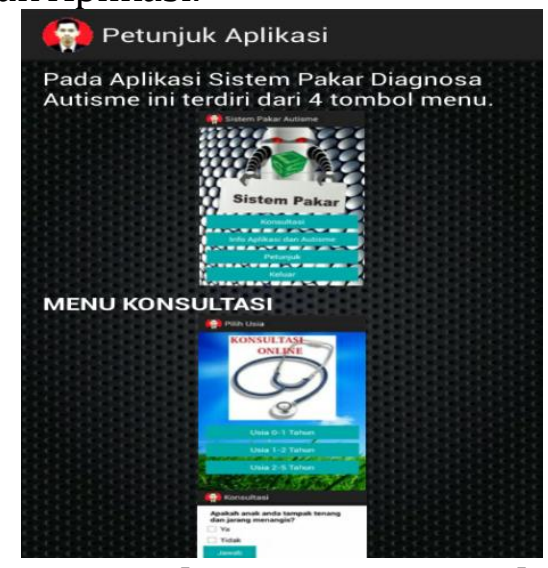

\section{Gambar 9. Tampilan Menu Petunjuk Aplikasi}

d. Tampilan Menu Sekolah dan Tempat Terapi.

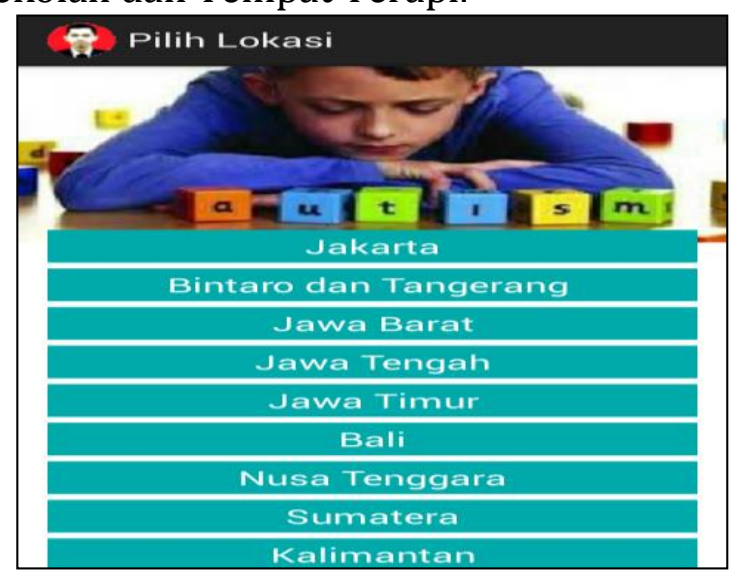

\section{Gambar 10. Tampilan Menu Sekolah dan Tempat Terapi}


e. Tampilan Menu Pilih Usia Anak

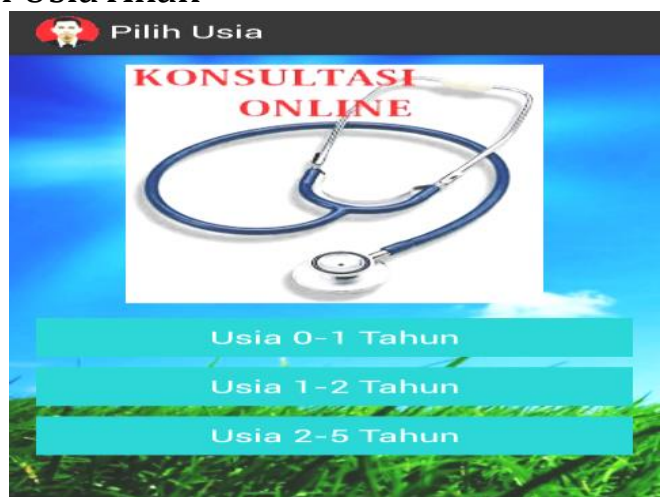

Gambar 12. Tampilan Menu Pilih Usia Anak

f. Tampilan Halaman Konsultasi

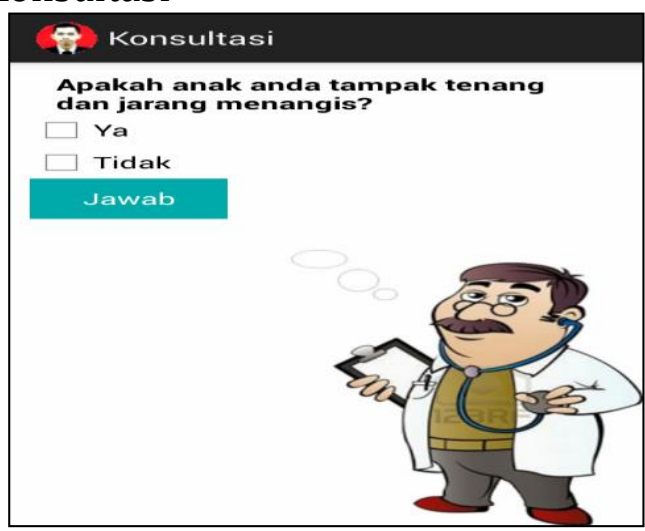

\section{Gambar 13. Tampilan Halaman Konsultasi}

g. Tampilan halaman hasil konsultasi, solusi dan terapi.

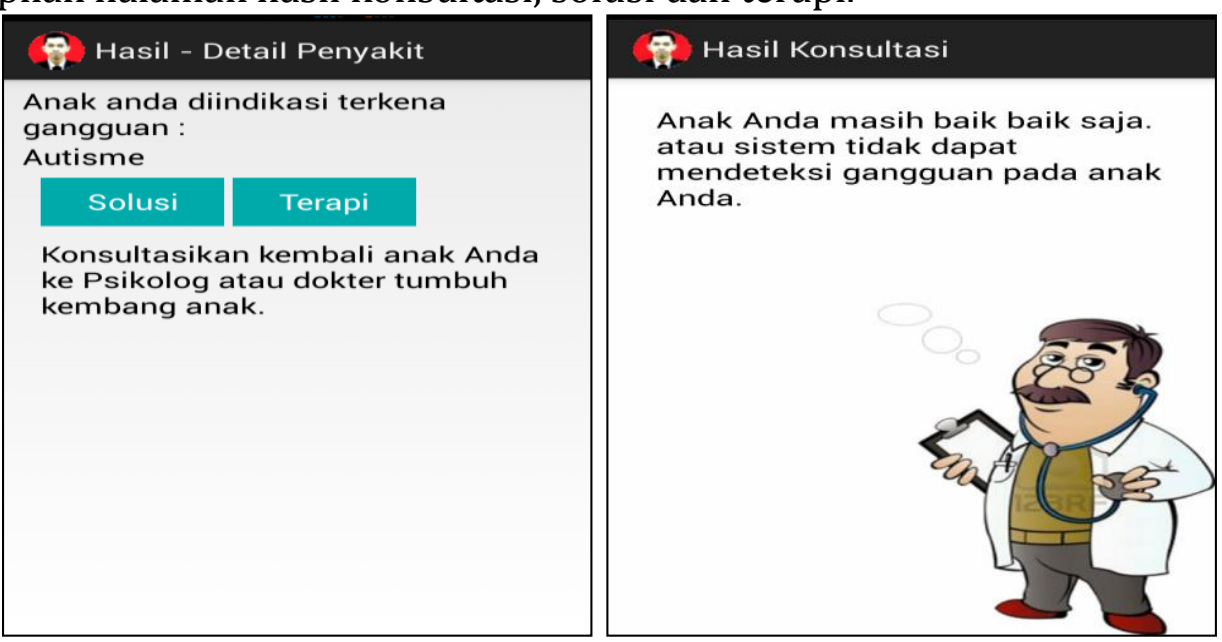

Gambar 14. Tampilan halaman hasil konsultasi, solusi dan terapi 


\section{SIMPULAN}

Berdasarkan pembahasan seperti yang telah diuraikan dapat ditarik kesimpulan bahwa ketika pembuatan aplikasi sistem pakar diagnosa gejala autisme ini dan hasil pengamatan yang penulis lakukan, maka menyimpulkan halhal sebagaiberikut :

1. Aplikasi sistem pakar diagnosis gejala autisme dan penanganannya denganmenggunakan metod forward chaining, dapat membantu pengguna umum untuk mengetahui dan dapat menangani anak yang diindikasi terkena autisme berdasarkan usia dan gejala ganggua nautisme.

2. Aplikasi sistem pakar diagnosa gejala autisme berbasis android dapat diakses oleh semua orang secara online dengan cara menginstall aplikasi sistem pakar tersebut di handphone android user.

3. Sistem pakar ini dibuat dengan tampilan yang sederhana dan user friendly sehingga para pengguna tidak kesulitan untuk menggunakannya.

\section{DAFTAR PUSTAKA}

[1] Perbawa, Doddy Satrya, Wawan Laksito, danDidik Nugroho. 2012. Sistem Pakar Perilaku Psikologis pada Anak dengan Metode Forward Chaining. ISSN: 1693-1173. Jakarta: Jurnal Ilmiah SinusVol. 2, No. 2, November 2012: $1-14$.

[2] Hayadi, B. Herawan. 2016. Sistem Pakar. Yogyaakarta: Deepublish.

[3] Rosnelly, Rika. 2012. Sistem Pakar Konsep dan Teori. Yogyakarta: Andi Offset.

[4] Pamoedji, Gayatri. 2010. 200 Pertanyaan dan Jawaban Seputar Autisme. Tangerang: Hasanah.

[5] Kursini. 2008. AplikasiSistemPakar. Yogyakarta: Andi Offset. 